\title{
Life history of gnathiid isopods-current knowledge and future directions
}

\author{
KATSUHIKO TANAKA* \\ Biological Environment Sector, Environmental Science Research Laboratory, Central Research Institute of Electric Power \\ Industry, 1646 Abiko, Abiko-shi, Chiba-ken 270-1194, Japan
}

Received 27 October 2006; Accepted 17 December 2006

\begin{abstract}
Gnathiidae is a family of Isopoda, showing a distinct morphology and ecology. Species in the family have ten walking legs compared to 14 for isopods in general. The life cycle of the Gnathiidae is biphasic including a fish-parasitic larval phase and a non-feeding adult phase, whereas most other isopods have a monophasic life cycle with directdeveloping young similar to adults in morphology and ecology. Although the ecological information on gnathiids has been described fragmentally, studies on the life cycles and population biology have increased dramatically since the 1980's. Larval biology including the host species, emergence pattern and predation risks during parasitism have also been studied from the view of fish disease and symbiotic interactions among fishes. Some authors reported the utilization patterns of benthic substrata and harem formation of adults therein. However, the ecological knowledge of gnathiids is based on a limited number of species of which the benthic habitats are known. Studies rarely identify larvae because of the lack, or insufficiency, of the taxonomic description of larvae of most species. The difficulty in identifying larvae has prevented detailed examination of ectoparasitic behaviour. Furthermore, gnathiid larvae emerging from the benthos or attaching to hosts have been investigated separately from benthic individuals. More efforts on taxonomy and the classification of larvae are necessary to elucidate the larval ecology and the integration of larval and adult biology.
\end{abstract}

Key words: ectoparasitism, emergence pattern, gnathiid isopods, habitat utilization, harem-formation, host fishes, life history, predation

\section{Introduction}

The Isopoda is a wide-spread crustacean order showing a diverse morphology and ecology. Isopods occur from the intertidal to continental shelf and deep sea in major parts of the world's oceans from polar to tropical waters (Schultz 1969; Brusca \& Brusca 2003). Some (sea louse and pill bugs) are terrestrial and are even found in deserts. These isopod crustaceans generally have no planktonic larvae. Eggs are laid in the female brood pouch, called a marspium, where embryogenesis progresses. Hatched juveniles crawling out from a brood pouch are miniatures of adult organisms and, in most aquatic species, start their benthic life in a similar way to the adults (Schultz 1969). However, some parasitic taxa have a different life cycle.

Many isopod species are known to be parasites of fishes or crustaceans (Schultz 1969, Wägele 1989, Brusca \& Wilson 1991). The parasitic mode ranges from temporal ec-

*Corresponding author: Katsuhiko Tanaka; E-mail: ktanaka@criepi. denkenor.jp toparasitism to permanent endoparasitism. Some feed facultatively on host blood or tissue, and others depend completely on host organisms as energy sources. Currently, 17 families are recognized as parasitic taxa, and each shows distinct morphology and ecology (Brusca \& Wilson 1991, Brandt \& Poore 2003). Particularly, Gnathiidae Leach, 1814 has been recognized as a highly specialized family among Isopoda.

Among the family Gnathiidae, over 170 species in 11 genera are known worldwide of which 24 species belonging to four genera have been recorded from Japanese coastal waters and adjacent areas (Cohen \& Poore 1994, Saito et al. 2000, Nunomura 2004, Nunomura \& Honma 2004, Smit \& Davies 2004, Tanaka 2004, 2005, Golovan 2006). It has been an enigmatic taxon because of its different body plan from those of other isopods. Isopods generally have seven free segments and seven pairs of ambulatory, natatory or prehensile legs on the thorax (Schultz 1969, Schram 1986). In contrast, gnathiids have only five pairs of walking legs (Monod 1926). Firstly, this is due to cephalization. The first thoracic segment is fused into the cephalosome and the ap- 
pendages form maxillipeds, called gnathopods in larvae and pylopods in adults. Secondly, the last thoracic segment is reduced and lacks appendages. These characteristics, retained in adult gnathiids possibly resulting from neoteny, were common in larvae of Isopoda, called manca. In addition to the fewer thoracic segments and limbs, the differences in ecology between larval and adult gnathiids are unusual among Isopoda. Larval gnathiids are known to be ectoparasites of fishes but adults cryptically inhabit benthic habitats and are regarded to be non-feeding (Smith 1904, Monod 1926). Adult gnathiids are also morphologically quite different from the larvae and show strong sexual dimorphism (Monod 1926, Schultz 1969).

The life history of Gnathiidae is not fully understood. However, the life cycle has been described for several species mainly after 1980s (Mouchet 1928, Stoll 1962, Wägele 1988, Klitgaard 1991, Tanaka \& Aoki 1998, Smit et al. 2003). The breeding biology, such as the harem-forming phenomenon, has been reported repeatedly (Upton 1987a, Wägele 1988, Klitgaard 1991, Barthel \& Brandt 1995). Host records and basic biology of fish-parasitic larvae have been accumulated through the investigation on the pathology (see Smit \& Davies 2004). Furthermore, recent publications focusing on cleaning interactions among tropical fishes suggested that gnathiid larvae occur abundantly in coral reef regions and play an important role as parasites in cleaning symbioses (Grutter 1999a, Arnal \& Côté 2000, Arnal \& Morand 2001, Bshary \& Grutter 2002).The biphasic life cycle including a fish-parasitic larval phase and nonfeeding adult phase may be an evolutionary product of inter- and intraspecific interactions which gnathiids and the ancestor have experienced and a good example in considering the diversity and adaptation of isopod crustaceans. Additionally, understanding the developmental and physiological divisions of labour in gnathiids and the evolutionary background may advance the general study of life histories of these animals. This review digests the current knowledge on the life history of gnathiids and discusses the problems to be solved.

\section{Aspects of the life cycle}

\section{Post-embryonic development}

Our understanding of the life cycle of Gnathiidae has emerged slowly because of taxonomic confusions primarily due to the morphological discontinuity between juveniles and adults (see Monod 1926). For adults (Fig. 1a, 1b), Leach (1814) described the genus Gnathia Leach, and Risso (1816) created the genus Anceus Risso, a synonym of Gnathia. On the other hand, gnathiid larvae with distinct appearance have been classified separately from adults. The genus Zuphea Risso was introduced for segmented larvae with segmented thorax by Risso (1816). The segmented larvae (Fig. 1c) are an active host-seeking form of gnathiid larvae. They attach on host fishes and engorge (Fig. 2). When the posterior thorax is dilated with host fluid the segmentation becomes indistinguishable (Monod 1926). For these post-feeding larvae (Fig. 1d), another genus Praniza Latreille was established by Latreille (1817). Although the old generic names for larvae have been sometimes used to express the developmental phase of larval gnathiids, zupheae are simply called segmented larvae and pranizae are called swollen or satiated larvae in this paper.

Adult and larval gnathiids were first united by the accidental observation of the metamorphism from a larva to an adult male by Hesse (1864). Smith (1904) and Monod (1926) also described the metamorphosis but they could not confirm the developmental pattern of larvae. Another important contribution was made by Mouchet (1928) who studied Paragnathia formica Omer-Cooper \& Omer-Cooper in addition to Gnathia maxillaris Montagu. He observed that small swollen larvae left the hosts and then moulted into segmented larvae in the next stage. Three size classes were distinguishable in segmented larvae of G. maxillaris, and thus Mouchet (1928) concluded that there are three instars, each containing a segmented form and swollen form. Therefore, first instars (segmented) of the gnathiids develop into third instars after alternating between ectoparasitism

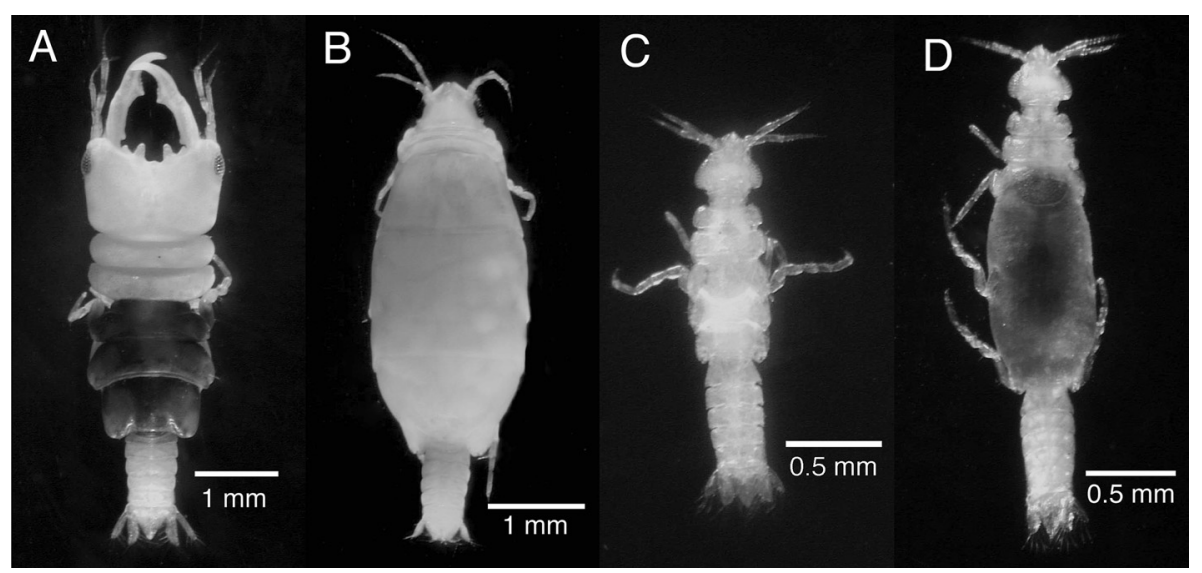

Fig. 1. External features of gnathiid isopods (Elaphognathia discolor for example). A: adult male, B: adult female, C: segmented larva, D: swollen larva. 


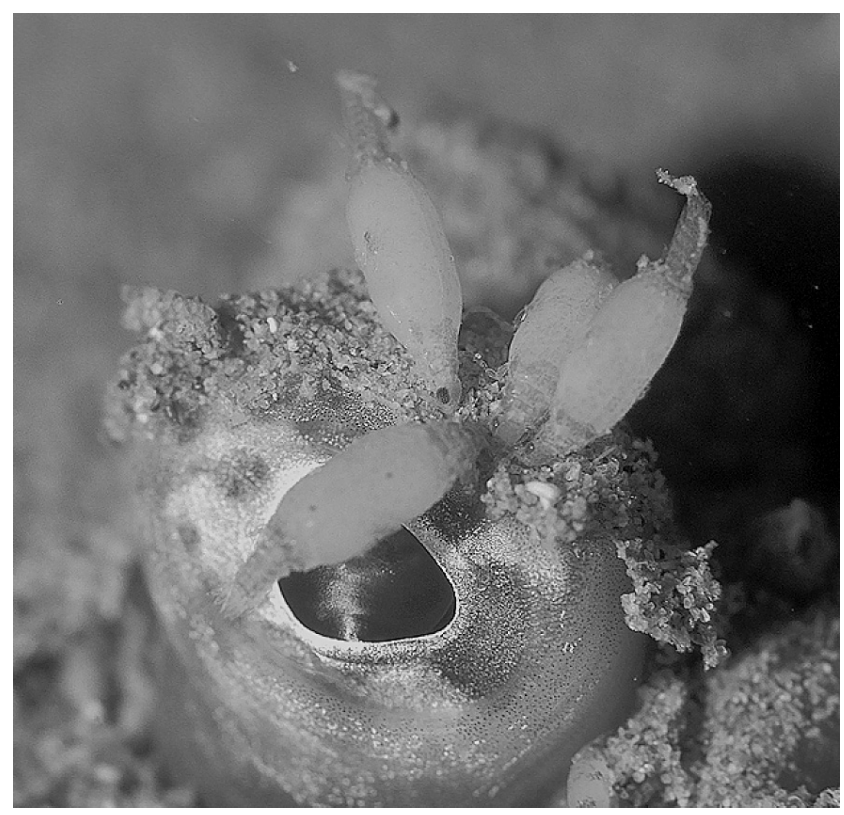

Fig. 2. Larvae of Elaphognathia discolor attaching on the eye of a flatfish (Pleuronectes yokohamae) in Shizugawa Bay, Miyagi, Japan.

and moulting (in a benthic habitat) twice. Third instars take the last blood meal and metamorphose into adults after leaving the hosts. The existence of three instars postulated by Mouchet (1928) was supported by Stoll (1962), who completed the life cycle of Panagnathia formica in the laboratory.

After Stoll (1962), life cycles similar to P. formica and $G$. maxillaris have been described for the Antarctic Caecognathia calva (Vanhöffen), Caecognathia abyssorum (G. O. Sars) from the deep water of the northeastern Atlantic, Elaphognathia cornigera (Nunomura) living in Japanese inertidal rocky shores and the South African Gnathia africana Barnard based on the analysis of size frequency distribution or laboratory culture. All of these gnathiids have three instars in the larval phase and are considered to metamorphose after shuttling three times between the fish host and benthic habitat (Fig. 3), because larvae are often found in habitats such as mud burrows and sponges (Wägele 1988, Klitgaard 1991, Tanaka \& Aoki 1998, Smit et al. 2003, Tanaka 2003).

The metamorphosis from larvae to adults occurs by a single moult in the genus Gnathia, Elaphognathia and Paragnathia. However, C. calva males need to moult twice to metamorphose, that is, final male larvae moult into a 'pre-male' stage and become true adult males by the subsequent moult (Wägele 1987, 1988). On the other hand, no subadult stage was observed in females of Caecognathia calva. Unfortunately, no observation of the metamorphism of C. abyssorum has been made (Klitgaard 1991), and it is unknown whether the 'pre-male' stage is specific to $C$. calva or shared among the genus. Generally, adult gnathiids have no functional mouthparts for feeding and are consid-

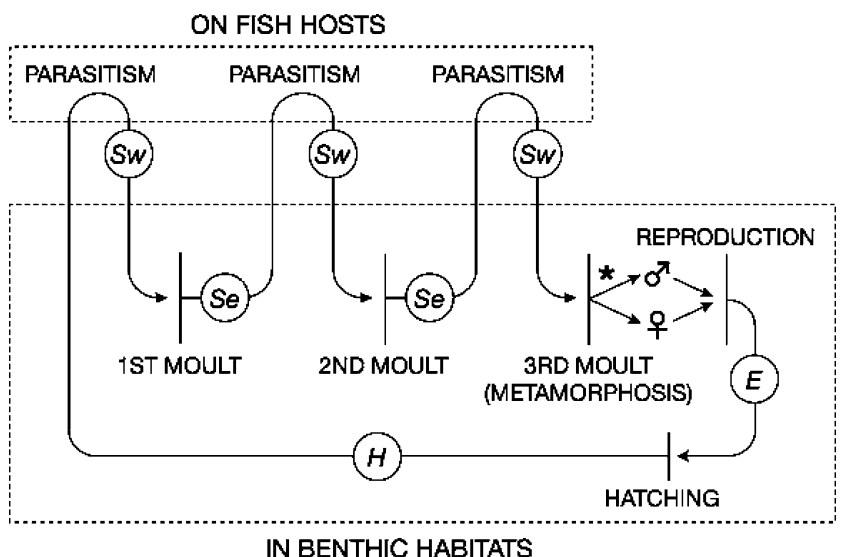

Fig. 3. The schematic life cycle of gnathiid isopods. Larvae shuttle between fish hosts and benthic habitats three times. Transition from final larvae to adults $(*)$ needs only a moult in most species but two moult in males of Caecognathia calva. E denotes eggs laid in a female brood pouch, $H$ denotes hatched larvae with segmented thorax, $\mathrm{Se}$ denotes segmented larvae (zupheae) and $\mathrm{Sw}$ denotes swollen larvae (pranizae).

ered not to take any food. Females are semelparous, and males are thought to die after consuming nutrients accumulated during larval stages (Smith 1904, Monod 1926, Wägele 1988, Klitgaard 1991, Tanaka \& Aoki 1998, Smit et al. 2003, Tanaka 2003).

\section{Lifespan}

Except for the case of male C. calva having a pre-male stage, six gnathiid species belonging to four genera shared a similar life cycle. However, the duration in each life stage and lifespan vary between species. According to Stoll (1962), hatched larvae of $P$. formica can survive 1.5 months without feeding. The first instars attach to the host and feed for 10-36 hours. Satiated larvae spend 6-13 weeks after the detachment from the host in the benthic habitat and then moult into the second instar. Second instars ectoparasitise a second host for 13 hours and moult to third instars after an additional 6-12 weeks non-feeding in the benthic habitat. The durations of parasitism and benthic inter-moult time in third instar are 48 hours and 7-8 weeks, respectively. In an England saltmarsh, the total lifespan of the gnathiid is regarded to be more than two years in males and about a year in females which pass away after the release of offspring (Upton 1987a).

Warm-temperate species have indicated higher growth rates and shorter lifespan than $P$. formica. Laboratoryreared specimens of Japanese E. cornigera showed intermoult periods of 12-20 days, and only 52 days on average were required to reach male adults after eclosion at $25^{\circ} \mathrm{C}$, near the water temperature experienced in the natural population in warmer months (Tanaka 2003). The generation time of the female gnathiids was also estimated to be about two months from spring to autumn, including a half month 
spent in the mother's brood pouch and one and half months as larvae, based on the field data (Tanaka \& Aoki 2000). The rapid growth of $E$. cornigera may be attributable to the warm waters in the study area (Tanaka \& Aoki 2000, Tanaka 2003). Smit et al. (2003) reported that, under the laboratory condition with a temperature range of $20-25^{\circ} \mathrm{C}$, G. africana took 8-10 days to moult after feeding while female larvae need 16-17 days for the final moult. Second and third instars of G. africana stayed in the segmented phase for several days after moulting. The embryonic development was considered to take 21 days. Finally, Smit et al. (2003) concluded that 62 days were required to complete the cycle from egg to egg.

The longest lifespan of gnathiids has been reported for the Antarctic C. calva. Wägele (1988) observed that third instars survived for up to two years and that a single adult male lived for more than two years. He assumed the life cycle of $C$. calva might take four to five years with 1 year for embryonic development and possibly three to four years for the larval stages. The retardation of the life cycle of $C$. calva was supposed to be a product of the low temperatures in the Antarctic region.

\section{Seasonal reproduction and population changes}

Although detailed investigations on natural populations of gnathiids have been conducted on only two intertidal species, the mud-burrowing P. formica (Amanieu 1963, Upton 1987a) and sponge-dwelling E. cornigera (Tanaka \& Aoki 2000, Tanaka 2003), remarkable seasonal population changes have been recorded. These include a period of limited female emergence (but continuous occurrence of males) during warmer months and a larval developmental halt during winter. In P. formica in England, females appeared in spring and died out after releasing broods in autumn. Larval males settled in late summer, matured in autumn and overwintered. In the following autumn, males were considered to breed with females of the next generation. Larval growth slowed or ceased under cool conditions $\left(4^{\circ} \mathrm{C}\right)$ in the laboratory (Stoll 1962). Upton (1987a) also suggested that mud temperatures below $7^{\circ} \mathrm{C}$ during winter months may have brought larval development to a halt. The longer breeding season in a more southern French population reported by Amanieu (1963) may support the hypothesis of temperature-dependent development.

Breeding in warmer months were also reported for $E$. cornigera in an intertidal rocky shore of Japan (Fig. 4). However, the lifespan of the species is much shorter than $P$. formica as mentioned in the previous section, and thus 3-4 generations were detected in the breeding season from spring to autumn (Tanaka \& Aoki 2000, Tanaka 2003). It was suggested that absence of females in winter was caused by the developmental halt of larvae and post-reproductive death of females in late autumn. Interestingly, only second stage satiated female larvae were observed together with males during winter. This may indicate that the moult from

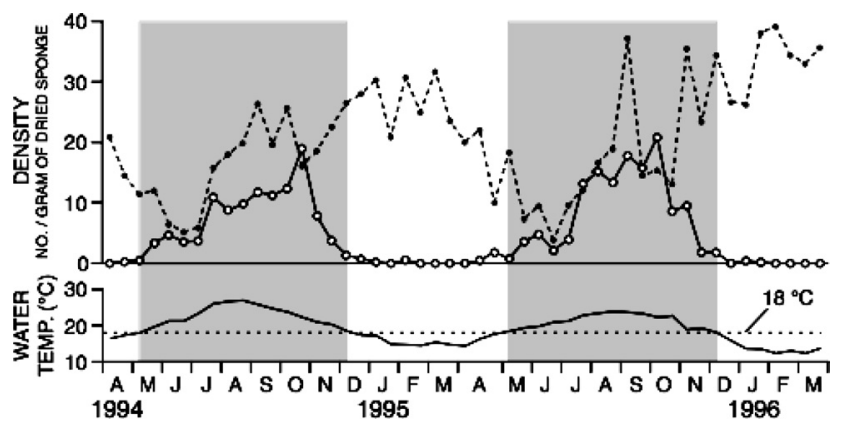

Fig. 4. Seasonal emergence pattern of adult Elaphognathia cornigera inhabiting the sponge Halichondria okadai on an intertidal rocky shore of Oura Bay, Shimoda, middle Japan. Upper: densities of adult male (broken line with closed circles) and female (solid line with open circles). Lower: surface water temperature. Shaded areas represent warmer months when water temperatures rise above $18^{\circ} \mathrm{C}$ (broken line) (after Tanaka \& Aoki 2000).

second to third instar is blocked by the low temperature of winter. Growth resumed during the following spring and matured individuals were considered to subsequently copulate with overwintering males (Tanaka 2003).

Although Klitgaard (1997) suggested continuous reproduction of Caecognathia robusta in the Denmark Strait and north of Iceland, a seasonal reproductive activity has been reported for other species living in cold waters. At the Faroe Islands, adult females of C. abyssorum were found only in samples from May-June, and reproduction was expected to start in spring and to end about July-August (Klittgard 1991). The Antarctic C. calva kept at temperatures between 0 and $-1{ }^{\circ} \mathrm{C}$ released broods between February and May (Wägele 1988). Klitgaard (1991) suggested that the development of $C$. abyssorum continues without any seasonal interruptions since the temperature in the depth interval, $150-500 \mathrm{~m}$, in which the gnathiid was collected, shows very little change throughout the year. Klitgaard (1997) also supposed that seasonal migration of possible hosts as food resources could be a trigger of seasonal breeding of gnathiids, instead of the seasonal changes in environment. Tanaka \& Aoki (2000) noted the relationship between the breeding season of E. cornigera and the population increase of the host goby Chaenogobius annularis Gill (previously Chasmichthys dolichognathus Hilgendorf), from spring to summer. However, the synchronous occurrence of gnathiids with hosts has not been assessed in detail. Further investigation on both the parasites and hosts will be needed to confirm the patterns summarized here.

\section{Ectoparasitism}

\section{Hosts fishes}

Numerous fishes including teleosts as well as elasmobranchs have been recorded as hosts of gnathiids in natural environments (Monod 1926, Honma et al. 1991, Grutter \& Poulin 1998, Heupel \& Bennett 1999, Arnal \& Morand 
Table 1. Orders and families of fish hosts of gnathiid isopods.

\begin{tabular}{|c|c|c|}
\hline $\begin{array}{l}\text { Order Chimaeriformes } \\
\text { Family Chimaeridae }^{1}\end{array}$ & $\begin{array}{l}\text { Order Gadiformes continued } \\
\text { Family Gadidae }^{1}\end{array}$ & $\begin{array}{l}\text { Order Perciformes continued } \\
\text { Family Gerreidae }^{1}\end{array}$ \\
\hline Order Orectolobiformes & Family Macrouridae $^{1}$ & Family Haemulidae $^{2}$ \\
\hline Family Orectolobidae $^{2}$ & Order Ophidiiformes & Family Nemipteridae $^{1}$ \\
\hline Family Hemiscylliidae $e^{2,3}$ & Family Ophidiidae $^{1}$ & Family Sparidae $e^{1,8,9}$ \\
\hline Family Ginglymostomatidae ${ }^{1}$ & Family Bythitidae ${ }^{1,2}$ & Family Lethrinidae $^{2}$ \\
\hline Order Carcharhiniformes & Order Zeiformes & Family Sciaenidae ${ }^{1}$ \\
\hline Family Triakididae $^{4}$ & Family Zeidae ${ }^{1}$ & Family Mullidae $e^{1,2,9}$ \\
\hline Family Scyliorhinidae $e^{4,5}$ & Order Gasterosteiformes & Family Pomacentridae $e^{2,8,9}$ \\
\hline Order Squatiniformes & Family Gasterosteidae $^{1}$ & Family Labridae $e^{1,2,8,9}$ \\
\hline Family Squatinidae $^{1}$ & Order Mugiliformes & Family Scaridae ${ }^{1,2}$ \\
\hline Order Rajiformes & Family Mugilidae $e^{1,8}$ & Family Notothenidae $^{11}$ \\
\hline Family Rhynchobatidae ${ }^{2}$ & Order Beloniformes & Family Harpagiferidae ${ }^{11}$ \\
\hline Family Rhinobatidae ${ }^{1,2}$ & Family Exocoetidae ${ }^{1}$ & Family Uranoscopidae ${ }^{1}$ \\
\hline Family Dasyatidae ${ }^{2,4}$ & Order Scorpaeniformes & Family Clinidae ${ }^{1}$ \\
\hline Family Torpedinidae $e^{1,5}$ & Family Scorpaenidae $^{1}$ & Family Gobiidae ${ }^{1,12}$ \\
\hline Family Rajidae $^{4}$ & Family Triglidae $^{1}$ & Family Siganidae $^{2}$ \\
\hline Family Myliobatidae $^{1}$ & Family Cottidae $^{1}$ & Family Acanthuridae $^{1}$ \\
\hline Order Coelacanthiformes & Family Liparidae $^{1}$ & Family Sphyraenidae $^{1}$ \\
\hline Family Coelacanthidae ${ }^{6}$ & Order Perciformes & Family Scombridae $^{1}$ \\
\hline Order Anguilliformes & Family Moronidae ${ }^{1}$ & Order Pleuronectiformes \\
\hline Family Anguillidae $e^{1,7}$ & Family Serranidae $e^{1,8,9,10}$ & Family Paralichthyidae ${ }^{1}$ \\
\hline Family Congridae $^{1}$ & Family Apogonidae $^{8}$ & Family Bothidae ${ }^{8}$ \\
\hline Order Salmoniformes & Family Carangidae ${ }^{1,8}$ & Family Pleuronectidae $^{1}$ \\
\hline Family Salmonidae $^{1}$ & Family Lutjanidae $^{2}$ & Family Soleidae $^{1}$ \\
\hline Order Gadiformes & Family Caesionidae $^{1}$ & Order Tetraodontiformes \\
\hline Family Merluccidae ${ }^{1}$ & Family Lobotidae ${ }^{1}$ & Family Balistidae ${ }^{2}$ \\
\hline
\end{tabular}

Superscripts indicate references. 1: Monod (1926), 2: Grutter \& Poulin (1998), 3: Heupel \& Bennett (1999), 4: Honma et al. (1991), 5: Smit \& Basson (2002), 6: Hughes (1995), 7: Mugridge \& Stallybrass (1983), 8: Marino et al. (2004), 9: Arnal \& Morand (2001), 10: Genc et al. (2005), 11: Wägele (1988), 12: Tanaka (2002)

2001). Gnathiids also occur in marine aquaria (Potts 1973, Marino et al. 2004) and attack fishes trapped or held in fish farming (Mugridge \& Stallybrass 1983, Drinan \& Rodger 1990). Grutter \& Poulin (1998) found gnathiid larvae on $70 \%$ of 56 fish species from 18 families in the Great Barrier Reef, Australia, and Arnal \& Morland (2001) listed eight teleosts as the hosts of gnathiids in the Mediterranean. In Japan, Honma et al. (1991) reported larval gnathiids, later cultured to adults and described in Nunomura \& Honma (2004), from five species of elasmobranchs. Currently, fishes belonging to at least 61 families in 18 orders are known as hosts of gnathiids (Table 1).

\section{Patterns of distribution within and amongst fish hosts}

Identification of gnathiid larvae to species has been rare in most studies. Therefore, the host preference of each gnathiids species is uncertain. However, larvae of the Mediterranean Gnathia vorax Lucas were collected from nine fish families (Arnal \& Morland 2001). Marino et al. (2004) also found $G$. vorax parasitising 11 fish species in a public aquarium in Messina, Italy. Thus, the host selectivity of $G$. vorax may not be strong. On the other hand, Grutter \& Poulin (1998) showed that the gnathiid infection in the
Great Barrier Reef was biased to some fish taxa. A significant difference in gnathiid abundance was also found among species in Labridae as well as in Siganidae. Additionally, high gnathiid loads ( $>50$ per fish) were recorded in five of six elasmobranchs. These results may indicate some degree of host specificity in gnathiids on the Great Barrier Reef. However, Grutter \& Poulin (1998) could not identify the larval gnathiids due to the lack of taxonomic information. More detailed surveys should be conducted based on a robust classification of gnathiid larvae in the future.

Gnathiids are generally found to occur on various parts of the hosts' bodies: gills, buccal cavity, nares, eyes, body surface, fins and, in the case of elasmobranchs, cloaca and claspers. Smit et al. (2003) suggested that juveniles of Gnathia africana attach to the part of fishes where they first contact. However, some authors have noted patchy distributions of gnathiid larvae on hosts. Heupel \& Bennett (1999), who examined the distribution of gnathiids on the epaulette shark Hemiscyllium ocellatum (Bonnaterre) reported significantly greater numbers of parasites at the pectoral fin bases, cloaca and claspers. The attachment of gnathiids to toxic gobies Gobiodon spp. were confined to the fins where toxin glands are less abundant, while it was evenly distrib- 
uted over the body of the non-toxic Paragobiodon xanthosomus (Bleeker) (Munday et al. 2003). The site of gnathiid attachment on some host species may be limited. This might indicate gnathiids prefer specific sites for attachment. However, the distribution patterns of parasites on hosts could also be affected by differential rates of accidental detachment and/or survival between different parts of the hosts' bodies. These alternative models remain to be tested experimentally.

\section{Duration and timing of feeding}

The feeding times of gnathiid larvae are regarded to be short, generally ranging from a few hours to a few days. Paragnathia formica larvae became satiated within 48 hours (Stoll, 1962). Smit et al. (2003) reported that the feeding time of larval G. africana was a few hours for first and second instars and 3 to 23 hours for third instars. Grutter (2003) reported that Gnathia sp. from the Great Barrier Reef only require up to an hour to feed and then leave the host.

There appears to be no consistent diurnal pattern of feeding activity of gnathiids, with reports of feeding occurring at night, at dawn, at dusk or during the day. Grutter (1999b) exposed unparasitized Hemigymnus melapterus (Bloch) to gnathiids in the field at Lizard Island, Australia, and observed higher numbers of gnathiids on fishes sampled in the late afternoon and night than in the early morning and midday. Another study at Lizard Island suggested that gnathiid larvae emerge from the benthos more often during the day than at night. However, it was concluded that including the late afternoon, with a higher rate of gnathiid emergence as shown by Grutter (1999b), with the rest of day may have inflated the overall emergence rates during the day (Grutter et al. 2000a). In the Caribbean, the number of gnathiid larvae captured per unit time sampled was significantly higher during the early-morning and near-dusk periods at two of three sampling sites (Chambers \& Sikkel 2002). However, Côté \& Molloy (2003) reported that the emergence of gnathiids was higher at night than during the day. The discrepancy in the emergence pattern of larval gnathiids among studies may be attributable to differences in the timing of feeding among gnathiid species. However, because of the poor taxonomic resolution of gnathiid larvae it is not possible to determine at this stage whether these differences are due to species-specific feeding activity or not. It should be noted that lunar and tidal cycles are also able to influence the temporal variation of larval gnathiids emerging from the benthos (Grutter et al. 2000a, Tinsley \& Reilly 2002).

\section{Predation risks}

Gnathiid larvae are small in size $(<1 \mathrm{~cm}$ in body length in general) and may be a potential food item of larger organisms which prey on small crustaceans. In fact, gnathiid larvae have been found in the gut contents of 20 fishes including wrasses, gobies, pipefish, butterfly fish and perch

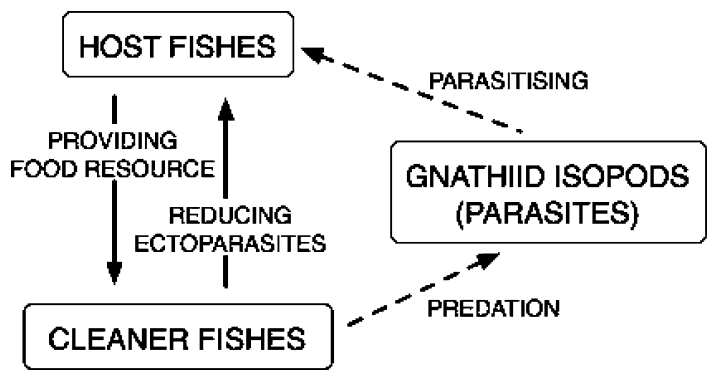

Fig. 5. Interactions among gnathiid isopods, host fishes and cleaner fishes. Arrows indicate positive (solid line) and negative (broken line) effects.

from the Indo-Pacific, the Caribbean, Brazil, Europe, and California (Grutter 2002). Interestingly, Tanaka (2002) found larvae of Elaphognathia cornigera in the gut of the host goby Chaenogobius annularis. Thus, the goby is both a host and predator of the gnathiid. Recent contributions (Grutter 1996, 1999a, Arnal \& Morand 2001) on the cleaning symbioses showed that cleaner fishes removing ectoparasites or other materials from the body surfaces of other fishes, referred to as hosts, customers or clients, feed on a large number of gnathiid larvae (Fig. 5). A cleaning wrasse Labroides dimidiatus on the Great Barrier Reef was estimated to take about 1,200 individuals of ectoparasites per day per fish, and $99.7 \%$ of them were gnathiid larvae (Grutter 1996). In the Mediterranean, approximately 200 gnathiids on average were found in the gut of a cleaner wrasse Symphodus melanocercus (Arnal \& Morand 2001). Some of these cleaners selectively feed on larger gnathiids (Grutter 1997). Therefore, larger individuals may be more vulnerable to predation.

Intensive predation might affect the density of gnathiids in the short term and, in long term, potentially cause an adaptive evolution of the life history traits. Although such an evolutionary process is almost impossible to observe, Grutter (2002) listed the possible counter-adaptation of parasites against predation pressure: infection when predators are scarce, rapid feeding on host fluid reducing the exposure time to cleaners, use of hiding place and so on. Gnathiidae was reported to have smaller body sizes than their closest free-living relatives (Poulin 1995), which could result from the selection pressure of cleaners favoring larger prey (Grutter 2002). Upton (1987a) also pointed out the lower number of life stages in gnathiids (three instars and one adult) compared to other crustaceans and suggested that the risks of mortality associated with each instar seeking out a new host and suitable benthic moulting site have favored a small number of stages.

\section{Habitat Utilization}

\section{Benthic substrata inhabited by gnathiids}

Larvae of fish-parasitic Gnathiidae have also been found together with adults in samples from benthic substrata col- 
lected by hand, dredges, epibenthic sledges, trawls and mud samplers (Monod 1926, Holdich \& Harrison 1980, Cohen \& Poore 1994). Paragnathia formica is common in saltmarshes and estuaries in northern Africa, western Europe and the British Isles, and both larvae and adults burrow nests on creek banks (Monod 1926, Upton 1987a,b). Caecognathia robusta and Elaphognathia cornigera utilize demosponges (Klitgaard 1991, 1997, Tanaka \& Aoki 1998). The Antarctic Caecognathia calva is also a spongedweller found in hexactinellid sponges (Wägle 1988). Gnathia africana in South Africa has been collected from sponges, ascidians and tubes of serpulid worms (see Smit et al. 2003). Taxonomic studies have reported other gnathiid species living in mud, rock crevices, submerged wood, coral rubble, dead barnacle shells, tubes of terrebellid polychaetes, colonies of cnidarians, algal turfs, seagrasses and sponges (Monod 1926, Holidich \& Harrison 1980, Cohen $\&$ Poore 1994). These benthic habitats are generally thought to provide resting and moulting place for larval gnathiids and breeding habitats for adult gnathiids.

\section{Differences in the benthic distribution among life stages}

Among life stages of a gnathiid species, differences in the habitat or distribution have been known. Wägele (1988) reported that third instars and adults of C. calva inhabit hexactinellid sponges in the Antarctic waters but he could not find first and second instars in sponges. Therefore, the first and second instars of $C$. calva may utilize unknown habitats, and the third instars were thought to penetrate small hexactinellids to reproduce after the final ectoparasitism (Wägele 1988). In E. cornigera in Japan, all three larval instars and adults were observed in a demosponge Halichondria okadai (Kadota) (Tanaka \& Aoki 1999). However, the larvae and adults showed different vertical distributions: larvae tended to concentrate in sponges near the mean tidal level but no apparent vertical distribution was observed in adults. Additionally, in G. africana, females have been recorded only from tubes of serpulid worms and never found in sponges or other substrata occupied by adult males and larvae (see Smit et al. 2003). Although the factors inducing the differences in distribution among life stages have not been confirmed, it may be due to the difference in ecological needs related to larval ectoparasitism and adult reproduction.

\section{Possible factors affecting the benthic distribution of gnathiids}

Larval gnathiids are known as good swimmers with swimming speeds of 10 to $20 \mathrm{~cm} / \mathrm{s}^{-1}$ (Grutter 2002). They may be able to move actively at small scales to settle into suitable habitats (Hesse 1864, Monod 1926, Smith 1904, Smit et al. 2003) Little is known about the habitat selection by gnathiid isopods but chemical communication among individuals has been reported. In a laboratory experiment, Upton (1987b) showed that all larval stages of P. formica were attracted to the mud containing adult males. The presence of benthic conspecific individuals was hypothesized to indicate to swollen larvae leaving host fishes suitable benthic settlement sites where post-settlement mortality due to anoxic mud was low (Upton 1987b). In other gnathiid species, the mechanism to locate suitable habitats has never been investigated. However, the detection of chemicals released from congeners or habitats themselves could improve settlement success and encountering rate of individuals in each species.

Although it is unknown whether gnathiids disperse long distances or not, passive movement depending on currents or host movement/migration may potentially increase dispersal and the spatial distribution of benthic gnathiids at larger scales. Since different fishes often show different home range and habitat use related to swimming ability (Green 1996, Syms \& Jones 2000, Fulton et al. 2001, Fulton \& Bellwood 2004, 2005), the host preference might influence the spatial distribution of gnathiids. On the other hand, the abundance and distribution pattern of benthic substratum utilized as habitat of gnathiids may be important for the successful settlement after leaving the host. However, the transportation of gnathiids by host fishes has not been assessed, and the benthic habitats are unknown in most gnathiid species. The possible influences of fish migration and habitat distribution on the benthic distribution of gnathiids warrants future investigation.

\section{Reproductive biology}

\section{Harem-forming phenomenon}

Breeding assemblages composed of a male and several females in the benthic habitat have been known in gnathiid isopods and often referred to as harems. In Paragnathia formica, up to 25 females were observed together with one male in a mud burrow (Upton 1987a). Wägele (1988) reported that harems, consisting of a male and up to $43 \mathrm{fe}$ males, were frequently present in Caecognathia calva. In Caecognathia abyssorum at the Faroe Islands, most of the adult males were found together with a number of adult females and/or swollen third instars (Klitgaard 1991). Barthel \& Brandt (1995) found four and five females of Caecognathia robusta coexisted with a male in a preoscular cavity of a sponge at NE Greenland and north of Iceland, respectively. The numbers of females coexisting with a male of $C$. abyssorum and C. robusta, which were much smaller than P. formica and C. calva, depend on the volumes of the sponge cavities (Klitgaard 1997). Males are often positioned at the entrance of burrows or cavities directing the head with elongated mandibles outside, probably to catch immature females or to guard the harem from potential invaders or predators (Upton 1987a, Klitgaard 1997).

Although the existence of harems is reported to be common in the family Gnathiidae (Brandt \& Wägele 1991, Cohen \& Poore 1994, Barthel \& Brandt 1995), Seed (1979) 
found no evidence of harems of Caecognathia agwillisi. Although no males and females were collected together, it was suggested that males of Gnathia africana live with one female at a time based on the sex ratio (Smit et al. 2003). Therefore, harem formation may not be a general rule in the family Gnathiidae. It might be related to the habitat utilization pattern as well as habitat structure (e.g. volume of cavities) for each gnathiid species.

\section{Sex ratio}

Male gnathiids are generally thought to have a longer lifespan than females (Upton 1987a, Wägele 1988, Tanaka 2003). Due to the lifespan differences, the sex ratio of adults may be expected to be biased towards males. However, females often exceeded males during the warm breeding period in field populations of both the intertidal $\mathrm{P}$. formica and Elaphognathia cornigera (Upton 1987a, Tanaka \& Aoki 2000, Fig. 4). The percentage of males of C. calva is very low (males : females $=1: 8$ ). These sex ratios, never strongly biased to males, might be caused by high mortality of males due to environmental conditions or intraspecific interaction. Higher post-settlement mortality in males than in females caused by anoxia in the lower end of the vertical distribution was recorded in $P$. formica (Upton 1987b). Wägele (1988) observed that intraspecific fights of C. calva obviously lead to the death of one of the rivals when two mature males were present in the laboratory. However, little is known about male-male competition in gnathiid isopods. Wägele (1988) and Upton (1987a) also referred to the possibility of environmental sex determination but no studies have investigated this. Further examination and discussion will be needed.

\section{Female reproductive traits}

Third stage female larvae of gnathiids moult into adults and copulate with males in the benthic habitat after leaving the third host (Wägele 1988, Klitgaard 1991, Tanaka \& Aoki 1998, Smit et al. 2003). The brood size of female gnathiids, ranging from tens to over a hundred, is different from species to species (Fig. 6). Upton (1987a) reported the release of broods of up to 140 larvae for $P$. formica. A female of C. calva produces approximately 130 eggs on average (Wägele 1988). The number of embryos per brood was $110 \pm 42.7$ in C. robusta and comparable to P. formica and C. calva (Klitgaard 1997). On the other hand, the brood size of C. abyssorum was about a third of C. calva, and the monthly average of the brood size of E. cornigera ranged from about 20 to 40. Smit et al. (2003) also recorded an average of 52 larvae released from a single female of $G$. africana. The body sizes of C. abyssorum and E. cornigera are relatively small, $3.6 \mathrm{~mm}$ and $2.2-2.6 \mathrm{~mm}$ on average, respectively, against $4-5 \mathrm{~mm}$ in $P$. formica, $6 \mathrm{~mm}$ in C. calva and $6.2 \mathrm{~mm}$ in C. robusta (Upton 1987a, Wägele 1988, Klitgaard 1997, Tanaka \& Aoki 2000). Although the difference in the size of embryos or first instar are also recog-

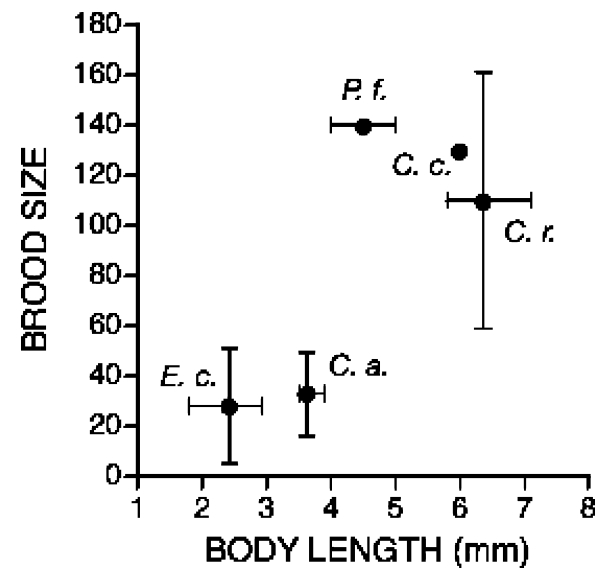

Fig. 6. Relationships between mean body length and mean brood size of five gnathiid species. Error bars indicate minimal and maximal values. Data are based on Klitgaard (1991) for Caecognathia abyssorum (C. a.) and Cacecognathia robusta (C. r.), Wägele (1988) for Caecognathia calva (C. c.) and Upton (1987a) for Paragnathia formica ( $P . f$.). Means and ranges of the body length and brood size of Elaphognathia cornigera (E. c.) are calculated from the original data used for Tanaka \& Aoki (2000).

nized among gnathiids (Klitgaard 1997), the brood size of female gnathids may, at least in some part, depend on the body size of each species.

The brood size of gnathiids may be influenced by environmental conditions. Tanaka \& Aoki (2000) showed that females of E. cornigera produced many small eggs from spring to summer but few large eggs in autumn. Although the female body length also changed seasonally with an increase during spring-summer and a decrease from summer onward, there was no significant difference in the brood volume against the female body size for each month. Therefore, Tanaka \& Aoki (2000) concluded that there is a trade-off between the quality and the quantity of eggs for $E$. cornigera, which may be related to seasonal changes in environmental factors, such as food availability and temperature conditions. However, quantitative examinations of female reproductive traits of gnathiids are scarce, and the related factors have not been fully examined. Researching the breeding biology of female gnathiids including the plasticity of reproductive traits may be a future subject for better understanding the physiological and ecological adaptations in Gnathiidae.

\section{Conclusion}

Since Hesse (1864) observed metamorphosis from a fishparasitic larvae into a non-feeding adult male, the complex life history of Gnathiidae has attracted much interest of researchers. The basic life cycle has been confirmed. The population dynamics and breeding biology, including harem forming phenomenon and female reproductive trait, have been reported based on benthic specimens. Studies on fish pathology and cleaning symbioses among fishes threw 
light on the parasitic behaviour of larval gnathiids. These contributions provided further areas of study, mostly on interspecific interactions concerning ectoparasitism and intraspecific interactions related to adult reproduction.

The ectoparasitic larval stages of gnathiids may be more commonly found than adults hiding in benthic habitats. A variety of fishes have been listed as hosts, and some information on the distribution patterns within and among host fishes and emergence patterns has been reported for larval gnathiids. Studies on the interactions between gnathiids, hosts and cleaners elucidated the predation risk involved in ectoparasitism by larval gnathiids. They may be quite important in consideration of feeding strategies of gnathiids as well as of the evolution of cleaning symbioses. However, the taxonomy of Gnathiidae has been solely based on morphology of adult males. The description of larvae is lacking or insufficient in most species. Therefore, the identification of gnathiid larvae is almost impossible. The taxonomical problem on larval gnathiids has prevented the estimation of the abundance, parasitic behaviour and impact on the host of each gnathiid species.

There was an attempt to separate a mixed population of gnathiid larvae into species employing molecular methods by Grutter et al. (2000b). Smit \& Davies (2004) also discussed the possibility of identifying gnathiid juveniles based on morphology and concluded that mouthparts could be used to distinguish larva if they were combined with other larval characters, for example, pleotelson shape. Developing the classification system of larval gnathiids would be a challenge, but is essential for furthering our understanding of the diversity and spatio-temporal emergence patterns of each species, and host-gnathiid and gnathiidcleaner fish interactions.

Investigations on benthic populations of gnathiids have clarified the life cycle, seasonal fluctuations and breeding biology. However, current knowledge is based on a limited number of species whose habitat has been detected. The cryptic habitats of most species are still unknown and the collection of a number of individuals of a particular species for quantitative analyses is generally difficult. The habitat of gnathiids could be determined by intensive surveys of benthic substrata but such surveys would be labour-intensive with no assurance of positive results. An alternative may be to monitor larval gnathiids emerging from the benthos or attaching to hosts and subsequently matching larvae with adult males for identification. Although there are difficulties in relating larvae to adult males, laboratory rearing techniques established by Stoll (1962), Wägele (1988), Tanaka (2003) and Smit et al. (2003) or the molecular methods conducted by Grutter et al. (2000b) can be applied.

It is well-known that Gnathiids form aggregations composed of a male and a number of semelaparous females in a burrow or cavity, and the mating system can be classified as semelparous harem polygynandry according to Shuster \& Wade (2003). Males are reported to form and guard harems by using forwardly protruding mandibles. However, current understanding of reproductive behaviour is based on fragmental descriptions for a few species, and little information is available on the response of females against males. Furthermore, not all gnathiid species seem to form harems. More intensive examination on the courtship, copulation, harem-formation and interactions among males are necessary to elucidate the breeding biology of gnathiids.

Finally, larval and adult biology should be integrated to understand the whole life history of Gnathiidae. Thus far, ectoparasitic larvae and benthic gnathiids have been generally investigated separately, probably due to the differences in the methods used to examine host-parasite relationships and benthic habitats and the aforementioned difficulty in identifying larvae. However, mortality and dispersal during the ectoparasitic phase of larvae are thought to potentially affect the abundance and distribution pattern of benthic individuals and further intraspecific interactions among them. Examination of the indirect effects of inter- and intraspecific interactions during larval stages on the ecology of cryptic non-feeding adults may further our understanding of the complex life cycles of gnathiids. It must be re-emphasised that the life history of Gnathiidae will never be fully understood until the larval taxonomy is resolved.

\section{Acknowledgements}

I am deeply indebted to M. Aoki for his generous support and critical discussion throughout my work. I also express my sincere thanks to Y. Yokohama for facilitating this research. I greatly appreciate A. Bellgrove for her helpful comments on the manuscript and language support. Many thanks to M. Tanaka for her critical reading of the manuscript.

\section{References}

Amanieu M (1963) Evolution des populations de Paragnathia formica (Hesse) au cours d'un cycle annuel. Bull Inst Océanogr, Monaco 60: 1-12.

Arnal C, Côté IM (2000) Diet of broadstripe cleaning gobies on a Barbadian reef. J Fish Biol 57: 1075-1082.

Arnal C, Morand S (2001) Importance of ectoparasites and mucus in cleaning interactions in the Mediterranean cleaner wrasse Symphodus melanocerucus. Mar Biol 138: 777-784.

Barthel D, Brandt A (1995) Caecognathia robusta (G. O. Sars, 1879) (Crustacea, Isopoda) in Geodia mesotriaena (Hentschel, 1929) (Demospongiae, Choristidae) at $75^{\circ} \mathrm{N}$ off NE Greenland. Sarsia 80: 223-228.

Brandt A, Poore GCB (2003) Higher classification of the flabelliferan and related Isopoda based on a reappraisal of relationships. Invertebr Syst 17: 893-923.

Brandt A, Wägele W (1991) Parasitic Isopoda of the family Gnathiidae from the Atlantic sector of the Southern Ocean. Redescription and remarks on the synonymy. Senckenb Marit 21: 233-261.

Brusca RC, Brusca GJ (2003) Invertebrates, 2 nd edition. Sinauer 
Associates, Sunderland, Massachusetts, $936 \mathrm{pp}$.

Brusca RC, Wilson GDF (1991) A phylogenetic analysis of the Isopoda with some classificatory recommendations. Mem Queensl Mus 31: 143-204.

Bshary R, Grutter AS (2002) Parasite distribution on client reef fish determines cleaner fish foraging patterns. Mar Ecol Prog Ser 235: 217-222.

Chambers SD, Sikkel PC (2002) Diel emergence patterns of ecologically important, fish-parasitic, gnathiid isopod larvae on Caribbean coral reefs. Caribb J Sci 38: 37-43.

Cohen BF, Poore GCB (1994) Phylogeny and biogeography of the Gnathiidae (Crustacea: Isopoda) with descriptions of new genera and species, most from south-eastern Australia. Mem Mus Vic 54: 271-397.

Côte IM, Molloy PP (2003) Temporal variation in cleanerfish and client behaviour: does it reflect ectoparasite availability?. Ethology 109: 487-499.

Drinan EM, Rodger HD (1990) An occurrence of Gnathia sp. ectoparasitic isopods, on caged Atlantic salmon. Bull Eur Ass Fish Pathol 10: 141-142.

Fulton C, Bellwood DR (2004) Wave exposure, swimming performance, and the structure of tropical and temperate reef fish assemblages. Mar Biol 144: 429-437.

Fulton C, Bellwood DR (2005) Wave-induced water motion and the functional implications for coral reef fish assemblages. Limnor Oceanogr 50: 255-264.

Fulton C, Bellwood D, Wainwright P (2001) The relationship between swimming ability and habitat use in wrasses (Labridae). Mar Biol 139: 25-33.

Genc E, Genc MA, Can MF, Genc E, Cengizler I (2005) A first documented record of gnathiid infestation on white grouper (Epiphelus aeneus) in Iskendrun Bay (north-eastern Mediterranean), Turkey. J Appl Ichthyol 21: 448-450.

Golovan OA (2006) Gnathia gurjanovae sp. n., a new species of Gnathiidae (Isopoda: Gnathiidae) from Peter the Great Bay, Sea of Japan. Russ J Mar Biol 32: 28-36.

Green AL (1996) Spatial, temporal and ontogenetic patterns of habitat use by coral reef fishes (Family Labridae). Mar Ecol Prog Ser 133: 1-11.

Grutter AS (1996) Parasite removal rates by the cleaner wrasse Labroides dimidiatus. Mar Ecol Prog Ser 130: 61-70.

Grutter AS (1997) Size-selective predation by the cleaner fish Labroides dimidiatus. J Fish Biol 50: 1303-1308.

Grutter AS (1999a) Cleaner fish really do clean. Nature 398: $672-673$

Grutter AS (1999b) Infestation dynamics of parasitic gnathiid isopod juveniles on a coral reef fish Hemigymnus melapterus. Mar Biol 135: 545-552.

Grutter AS (2002) Cleaning symbiosis from the parasites' perspective. Parasitology 124: S65-S81.

Grutter AS (2003) Feeding ecology of the fish ectoparasite Gnathia sp. (Crustacea: Isopoda) from the Great Barrier Reef, and its implications for fish cleaning behaviour. Mar Ecol Prog Ser 259: 295-302.

Grutter AS, Poulin R (1998) Intraspecific and interspecific relationships between host size and the abundance of parasitic larval gnathiid isopods on coral reef fishes. Mar Ecol Prog Ser 164: 263-271.
Grutter AS, Lester RJG, Greenwood J (2000a) Emergence rates from the benthos of the parasitic juveniles of gnathiid isopods. Mar Biol Prog Ser 207: 123-127.

Grutter AS, Morgan JAT, Adlard RD (2000b) Characterising parasite gnathiid isopod species and matching life stages with ribosomal DNA ITS2 sequences. Mar Biol 136: 201-205.

Hesse E (1864) Mémoire sur les pranizes et ancées. Mém Savants Etrangers, Acad Sci, Paris 18: 231-302.

Heupel MR, Bennett MB (1999) The occurrence, distribution and pathology associated with gnathiid isopod larvae infecting the epaulette shark, Hemiscyllium ocellatum. Int J Parasitol 29: 321-330.

Holdich DM, Harrison K (1980) The crustacean isopod genus Gnathia Leach from Queensland waters with descriptions of nine new species. Aust J Mar Freshwater Res 31: 215-240.

Honma Y, Tsunaki S, Chiba A, Ho J-S (1991) Histological studies on the juvenile gnathiid (Isopoda, Crustacea) parasitic on the branchial chamber wall of the stingray, Dasiatis akajei, in the Sea of Japan. Rep Sado Mar Biol Stat, Niigata Univ 21: 37-47.

Hughes GM (1995) The gills of the coelacanth, Latimeria chalumnae, a study in relation to body size. Philos Trans R Soc Lond, Ser B 347: 427-438.

Klitgaard AB (1991) Gnathia abyssorum (G. O. Sars, 1872) (Crustacea, Isopoda) associated with sponges. Sarsia 76: 33-39.

Klitgaard AB (1997) The distribution and habitats in the North Atlantic of two gnathiid species (Crustacea, Isopoda_ and their reproductive biology in the Denmark Strait and north of Iceland. Meddr Grønland, Biosci 47: 5-32.

Latreille PA (1817) Les Crustacés, les arachnides et les insectes. In: La règne animal distribué d'après son organisation, pour servir de base à l'histoire naturelle des animaux et d'introduction à l'anatomie comparée (ed Cuvier G). Edition 1, volume 3, Déterville, Paris, pp. 1-653.

Leach WE (1814) Crustaceology. In: The Edinburgh encyclopaedia 7 (ed Brewster D). Baldwin, London, pp. 383-487.

Marino F, Giannetto S, Paradiso ML, Bottari T, De Vico G, Macri B (2004) Tissue damage and haematophagia due to praniza larvae (Isopoda: Gnathiidae) in some aquarium seawater teleosts. Dis Aquat Org 59: 43-47.

Monod T (1926) Les Gnathiidae. Essai monographique (morphologie, biologie, systématique). Mém Soc Sci Nat Maroc 13: $1-667$.

Mouchet S (1928) Note sur le cycle évolutif des Gnathiidae. Bull Soc Zool Fr 53: 392-400.

Mugridge PER, Stallybrass HG (1983) A mortality of eels, Anguilla anguilla L., atributed to Gnathiidae. J Fish Dis 6: 81-82.

Munday PL, Schubert M, Baggio JA, Jones GP, Caley MJ, Grutter AS (2003) Skin toxins and external parasitism of coral-dwelling bobies. J Fish Biol 62: 976-981.

Nunomura N (2004) Isopod crustaceans collected from Aomori Prefecture, northern Japan. Contr Biol Lab, Kyoto Univ 29: 351-360.

Nunomura N, Honma Y (2004) Gnathia capillata, a new species of the genus Gnathia (Crustacea, Isopoda) from Sado Island, the Sea of Japan. Contr Biol Lab, Kyoto Univ 29: 343-349.

Potts GW (1973) Cleaning symbiosis among British fish with special reference to Crenilabrus melops (Labridae). J Mar Biol Ass UK 53: 1-10. 
Poulin R 1995. Evolutionary influences on body size in free-living and parasitic isopods. Biol J Linn Soc 54: 231-244.

Risso A (1816) Histoire naturelle des Crustacés des environs de Nice. Librairie Grecque-Latine-Allemande, Paris, 175 pp.

Saito N., Itani G, Nunomura N (2000) A preliminary check list of isopod crustaceans in Japan. Bull Toyama Sci Mus 23: 11-107.

Schram RR (1986) Crustacea. Oxford University Press, Oxford, 606 pp.

Schultz GA (1969) How to know the marine isopod crustaceans. WM. C. Brown Company Publishers, Dubuque, Iowa, 359 pp.

Seed WF (1979) The family Gnathiidae (Crustacea: Isopoda). A new Victorian species. Vic Nat 96: 56-62.

Shuster SM, Wade MJ (2003) Mating systems and strategies. Princeton University Press, Princeton, New Jersey, 533 pp.

Smith G (1904) Metamorphosis and life-history of Gnathia maxillaris. Mitteil zool Stat Neapel 16: 469-479.

Smit N, Basson L (2002) Gnathia pantherina sp. n. (Crustacea: Isopoda: Gnathiidae), a temporary ectoparasite of some elasmobranch species from southern Africa. Folia Parasitol 49: 137-151.

Smit N, Davies AJ (2004) The curious life-style of the parasitic stages of gnathiid larvae. Adv Parasitol 58: 289-391.

Smit N, Basson L, Van As JG (2003) Life cycle of the temporary fish parasite, Gnathia africana (Crustacea: Isopoda: Gnathiidae). Folia Parasitol 50: 135-142.

Stoll C (1962) Cycle évolutif de Paragnathia formica (Hesse) (Isopode-Gnathiidae). Cah Biol Mar 3: 401-416.

Syms C, Jones GP (2000) Disturbance, habitat structure, and the dynamics of a coral-reef fish community. Ecology, 81: 2714-2729.

Tanaka K (2002) Predation risks involved in the parasite behaviour of gnathiid isopods (Crustacea). Jpn J Benthol 57: 85-89 (In Japanese with English abstract)

Tanaka K (2003) Population dynamics of the sponge-dwelling gnathiid isopod Elaphognathia cornigera. J Mar Biol Ass UK 83: 95-102.

Tanaka K (2004) A new species of Gnathia (Isopoda: Cymoth- oida: Gnathiidae) from Ishigaki Island, the Ryukyus, southwesternJapan. Crustac Res 33: 51-60.

Tanaka K (2005) A new genus and species of gnathiid isopod (Isopoda, Gnathiidae) from the Ryukyus, southwestern Japan. J Crust Biol 25: 565-569.

Tanaka K, Aoki M (1998) Crustacean infauna of the demosponge Halichondria okadai (Kadota) with reference to the life cycle of Gnathia sp. (Isopoda: Gnathiidea). In: Sponge Sciences-Multidisciplinary Perspectives (eds Watanabe Y, Fusetani N). Springer-Verlag, pp. 259-267.

Tanaka K, Aoki M (1999) Spatial distribution patterns of the sponge-dwelling gnathiid isopod Elaphognathia cornigera (Nunomura) on an intertidal rocky shore of the Izu Peninsula, southern Japan. Crustac Res 28: 160-167.

Tanaka K, Aoki M (2000) Seasonal trait of reproduction in a gnathiid isopod Elaphognathia cornigera (Nunomura, 1992). Zool Sci 17: 467-475.

Tinsley MC, Reilly SD (2002) Reproductive ecology of the saltmarsh-dwelling marine ectoparasite Paragnathia formica (Crustacea: Isopoda). J Mar Biol Ass UK 82: 79-84.

Upton NPD (1987a) Asynchronous male and female life cycles in the sexually dimorphic, harem-forming isopod Paragnathia formica (Crustacea: Isopoda). J Zool, Lond 212: 677-690.

Upton NPD (1987b) Gregarious larval settlement within a restricted intertidal zone and sex differences in subsequent mortality in the polygynous saltmarsh isopod Paragnathia formica (Crustacea: Isopoda). J Mar Biol Ass UK 67: 663-678.

Wägele JW (1987) Description of the postembryonal stages of the Antarctic fish parasite Gnathia calva Vanhöffen (Crustacea: Isopoda) and synonymy with Heterognathia Amar \& Roman. Polar Biol 7: 77-92.

Wägele JW (1988) Aspects of the life-cycle of the Antarctic fish parasite Gnathia calva Vanhöffen (Crustacea: Isopoda). Polar Biol 8: 287-291.

Wägele JW (1989) Evolution und phylogenetisches System der Isopoda. Stand der Forschung und neue Erkenntnisse. Zool Stuttgart 140: 1-262. 